\title{
Rifampicin-resistant Mutants of Streptomyces coelicolor A3(2)
}

\author{
By K. F. CHATER \\ John Innes Institute, Colney Lane, Norwich NOR $70 \mathrm{~F}$
}

(Received 9 July I973)

\begin{abstract}
SUMMARY
Studies with whole cells and crude cell-free extracts of Streptomyces coelicolor A3(2) indicate that its RNA polymerase, though sensitive to rifampicin, is less so than most bacterial RNA polymerases. Of two other streptomycetes examined, one resembled $S$. coelicolor A3(2) and the other was more like other prokaryotes in respect of rifampicin sensitivity of its RNA polymerase. Three genetic map locations for rifampicin-resistance (rif) mutations of $S$. coelicolor A3(2) were determined, one (rifA) at 6 o'clock on the conventional linkage map, very close to $\operatorname{sir} A$, one $($ rif $B)$ at I I o'clock, between $\operatorname{leu} A$ and $t$ hi $C$, and a third (rifC) at 7 o'clock, between str $A$ and phe $A$. In representative rifB and $C$ mutants, RNA synthesis was resistant to rifampicin in whole cells, but not in extracts, whereas in several rif $A$ mutants RNA synthesis was equally resistant both in whole cells and in extracts, suggesting that the rif $A$ gene may specify part of the RNA polymerase. None of more than 100 rif $A$ mutants isolated possessed morphological abnormalities attributable to the rif $A$ mutation.
\end{abstract}

\section{INTRODUCTION}

It has previously been pointed out (Chater \& Hopwood, 1973) that an investigation of the DNA-dependent RNA polymerase of Streptomyces coelicolor A3(2) is pertinent to our studies of differentiation in this morphologically complex prokaryote (Hopwood, Wildermuth \& Palmer, I970; Chater, 1972). One approach to the study of this enzyme is the isolation of mutants resistant to rifampicin, which in other bacteria usually have an altered RNA polymerase (Wehrli \& Staehelin, 197I). It is particularly interesting to note that in Bacillus subtilis such mutants are often defective in sporulation (Doi, Brown, Rodgers \& Hsu, 1970; Sonenshein \& Losick, 1970).

The present paper describes the isolation of three kinds of rifampicin-resistant mutants of Streptomyces coelicolor and the identification of probable RNA polymerase mutants among them.

\section{E T H OD S}

Organisms. All mutant strains were derived by mutation and recombination from Streptomyces coelicolor A3(2) (Hopwood, 1959; S. violaceoruber according to Kutzner \& Waksman, 1959). They are listed in Table I, and a linkage map of all the markers employed is given in Fig. I. In addition, two independently isolated wild-type streptomycetes were used. Our strain 1326 was 'strain 66' of Lomovskaya, Mkrtumian, Gostimskaya \& Danilenko (1972), kindly sent by Dr N. D. Lomovskaya, Institute of Genetics and Selection of Microorganisms, Moscow, U.S.S.R.; this strain has been variously classified as $S$. coelicolor or S. lividans (Hopwood \& Wright, I973). Our strain I I6o was S. albus, obtained in I 954 from the Commonwealth Mycological Institute, Kew, Surrey (their strain 52766).

Chemicals. Rifampicin was a gift from Dr J. Nüesch of Ciba-Geigy A.G., Basle, 


\title{
Table I. Mutant strains of Streptomyces coelicolor A3(2)
}

\begin{abstract}
All strains are of NF fertility type except for 3 I I which is If (Hopwood, Chater, Dowding \& Vivian, 1973). Where rif mutants were derived from a sensitive strain after mutagenesis, the strain number of the parent strain is given under 'Source' with the mutagen in brackets (NTG $=N$-methyl- $N^{\prime}$-nitro- $N$-nitrosoguanidine; $\mathrm{MOP}=8$-methoxypsoralen + near u.v. irradiation). Where strains were derived by recombination, the parent strains are indicated under 'Source'.
\end{abstract}

\begin{tabular}{|c|c|}
\hline Strain no. & Genotype \\
\hline $3 \mathrm{II}$ & hisAI leuAI strAI \\
\hline A32I & uraAI \\
\hline 774 & $\arg A I$ his C9 proAI strAI \\
\hline 782 & $\arg A I$ cys $C_{3}$ his $A I$ mthB2 strAI \\
\hline 876 & $\arg A I$ cys $C_{3}$ his $C_{9}$ phe AI proAI strAI \\
\hline 957 & $\arg A I$ cys $C_{3}$ pheAI strAI thiC2 \\
\hline $\mathrm{J} 222$ & rifAIor uraAI \\
\hline $\mathrm{J} 223$ & cys $_{3}$ rifAIOI \\
\hline 3229 & rifBIO3 uraAI \\
\hline $\mathrm{J} 245$ & rifBIog uraAI \\
\hline $\mathrm{J} 259$ & rifCII4 uraAI \\
\hline $\mathrm{J} 264$ & rif $A I I 8$ uraAI \\
\hline J27I & cys $C_{3}$ phe $A I$ proAI rifBIo3 strAI \\
\hline J30I & pheAI rifAI I4 \\
\hline J3 I 7 & pheAI proAI rifBIog strAI \\
\hline 3335 & his $\mathrm{C}_{9}$ rifBro3 \\
\hline $\mathrm{J} 365$ & $\arg A I$ cys $C_{3}$ his $C_{9}$ phe AI proAI rifAI22 str $A I$ \\
\hline $\mathrm{J} 370$ & $\arg A I$ cys $C_{3}$ his $C_{9}$ phe $A I$ proAI rif $A 124$ str $A I$ \\
\hline $\mathrm{J} 372$ & pheAI rif $A 124$ str $A I$ \\
\hline J373 & pheAI proAr rifBr25 strAI \\
\hline $\mathbf{3} 386$ & $\arg A I$ cys $C_{3}$ his $C_{9}$ phe $A I$ proAI rifBI 25 str $A I$ \\
\hline J398 & pheAI rif $A I 22 \operatorname{str} A T$ \\
\hline $\mathrm{J} 5 \mathrm{I} 5$ & riffis26 \\
\hline
\end{tabular}

Source

D. A. Hopwood A. Vivian D. A. Hopwood D. A. Hopwood D. A. Hopwood D. A. Hopwood A32 I(NTG) $\mathrm{J} 222 \times 782$ A32 I (NTG) A 32 I (MOP) A32I(MOP) A32 I (MOP) J229 $\times 876$ $\mathbf{J} 259 \times 876$ $\mathrm{J} 245 \times 876$ $\mathrm{J} 229 \times 774$ 876 (NTG) $876(\mathrm{NTG})$ $\mathrm{J} 370 \times \mathrm{A} 32 \mathrm{I}$ $\mathrm{J} 386 \times$ A 32 I 876(NTG) $\mathrm{J} 365 \times \mathrm{A} 32 \mathrm{I}$ A3(2)(MOP)

Switzerland, and streptolydigin was a gift from Dr G. B. Whitfield of the Upjohn Co., Kalamazoo, Michigan, U.S.A.; unlabelled ribonucleoside triphosphates were obtained from P-L Biochemicals, Milwaukee, Wisconsin, U.S.A.; $\left.{ }^{3} \mathrm{H}\right] \mathrm{UTP}$ (I3 Ci/mmol; $0.5 \mathrm{mCi} /$ $\mathrm{ml})$ and $\left[{ }^{3} \mathrm{H}\right]$ uridine $(5.5 \mathrm{Ci} / \mathrm{mmol} ; \mathrm{I} \mathrm{mCi} / \mathrm{ml})$ from the Radiochemical Centre, Amersham, Buckinghamshire; dithiothreitol from B.D.H. Biochemicals, Poole, Dorset; calf thymus DNA from Worthington Biochemicals, Freehold, New Jersey, U.S.A.; and egg-white lysozyme (grade I) from Sigma, London.

Methods of culture. Minimal (MM) and complete (CM) agar media, supplements, and general methods of culture were as described by Hopwood (1967). Rifampicin-supplemented plates were poured after the addition of a freshly prepared solution of rifampicin in methanol to molten agar medium cooled to $50{ }^{\circ} \mathrm{C}$. Final concentrations were 50 to $200 \mu \mathrm{g} / \mathrm{ml}$ for the isolation of mutants, and 25 or $50 \mu \mathrm{g} / \mathrm{ml}$ for classification of recombinants by replica plating. Mycelium for the preparation of cell-free extracts was grown in liquid yeast-extract-maltextract medium (Townsend, Wright \& Hopwood, I97I) containing $33 \%(\mathrm{w} / \mathrm{v})$ sucrose and $0.5 \%(\mathrm{w} / \mathrm{v}) \mathrm{MgCl}_{2}$. The medium was dispensed in 400 to $500 \mathrm{ml}$ volumes in 21 Erlenmeyer flasks. Each flask was inoculated with $10^{9}$ to $10^{10}$ spores and incubated for 24 to $48 \mathrm{~h}$ in a rotary shaker at about $200 \mathrm{rev} . / \mathrm{min}$. Mycelium was harvested by centrifugation, washed once with distilled water, and stored frozen at $-20{ }^{\circ} \mathrm{C}$. Up to $5 \mathrm{~g}$ (packed wet wt) mycelium was obtained from each flask.

Isolation of rifampicin-resistant mutants. Spore suspensions were treated with $N$-methyl$N^{\prime}$-nitro- $N$-nitrosoguanidine (Delić, Hopwood \& Friend, I970) or with 8-methoxypsoralen 


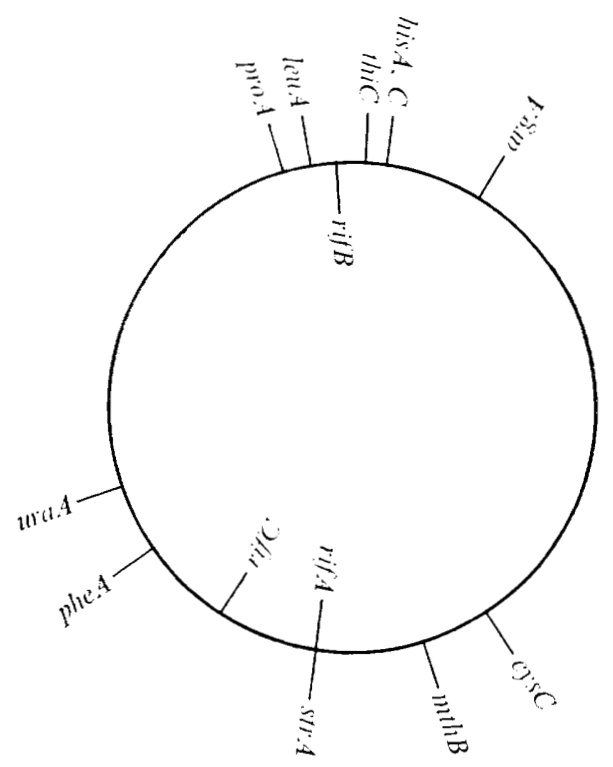

Fig. I. Linkage map of markers employed. The gene symbols and map locations of markers outside the circle are from Hopwood (1967). The locations of the three rif (rifampicin-resistance) genes described in this paper are inside the circle.

and near u.v. light (Townsend et al. 197I) and then incubated in the absence of rifampicin to allow spore germination and expression of resistance. This incubation took one of three forms: (i) spores were incubated in nutrient broth (Difco-Bacto) supplemented with glucose $(0.5 \%, \mathrm{w} / \mathrm{v})$ for 5 to $7 \mathrm{~h}$ before plating directly on medium containing rifampicin; (ii) the incubation in nutrient broth was extended to $\mathrm{I} 6 \mathrm{~h}$ and was followed by a brief sonication to disperse clumps of mycelium before plating on medium containing rifampicin; or (iii) mutagen-treated spores were spread on cellophane discs laid on medium lacking rifampicin, and incubated overnight before transfer to medium containing the antibiotic. In some cases, a further transfer of cellophane overlays to fresh rifampicin medium was made after two more days to reduce the background growth that occurred as the rifampicin lost its activity. Resistant colonies were picked off after 4 days' incubation. Rifampicin concentrations were 50 to $200 \mu \mathrm{g} / \mathrm{ml}$. In all cases, the frequency of resistant mutants was much greater after mutagenic treatment than in untreated controls.

Genetic analysis. Two methods were employed. Map locations of individual mutations were determined by the haploid selection method of Hopwood (I967). In addition, when the first rif locus had already been identified a rapid method of preliminary mapping of further mutations was also used, in which master plates with up to 24 patches of strains to be tested were replica plated to CM spread with a lawn of an appropriately marked strain, giving up to 24 crosses per plate. These crosses were replica plated after 4 days' incubation to media selecting certain classes of recombinants. Full details of the strains and selections employed are given in Results. Such methods have been used previously in the identification of fertility variants (Hopwood, Harold, Vivian \& Ferguson, 1969) and in the rapid classification of u.v.-sensitive mutants of A3(2) (Harold \& Hopwood, I972).

Assay of RNA synthesis in whole cells. Glass-fibre filters $(2.5 \mathrm{~cm}$; Whatman, GF/C) were cut into quadrants and laid on an appropriately supplemented MM plate. To each quadrant was added $0.01 \mathrm{ml}$ spore suspension (about $10^{7}$ spores). After $\mathrm{I} 8 \mathrm{~h}$ incubation the quadrants 
were transferred to a dish containing a shallow layer of pre-incubation medium (liquid minimal medium containing $0.5 \%(\mathrm{w} / \mathrm{v})$ glucose, uridine $(2 \mu \mathrm{g} / \mathrm{ml})$ and substances required for the growth of auxotrophs) and incubated at $30^{\circ} \mathrm{C}$ for $\mathrm{I} h$ before transfer to assay medium of the same composition as pre-incubation medium, but containing [ ${ }^{3} \mathrm{H}$ ] uridine ( $\mathrm{r} \mu \mathrm{Ci}$ / $\mu \mathrm{mol}, 2 \mu \mathrm{g} / \mathrm{ml})$. The assay medium formed a shallow layer in a dish, and was kept at $30{ }^{\circ} \mathrm{C}$. Where zero time samples were required, quadrants were dipped transiently into the assay medium and then dropped into $5 \mathrm{ml}$ ice-cold $5 \%(\mathrm{w} / \mathrm{v})$ trichloroacetic acid (TCA). Further quadrants were then placed in the assay medium and removed to $5 \%$ TCA after appropriate times of incubation. Samples were washed in two $100 \mathrm{ml}$ volumes of $2 \% \mathrm{TCA}$ and in one $50 \mathrm{ml}$ volume of ethanol before drying at $80^{\circ} \mathrm{C}$. The dry samples were added to scintillation vials containing $5 \mathrm{ml}$ scintillation fluid [0.5\% (w/v) butyl PBD (Ciba) in toluene], and their radioactivity measured in a Beckman LS-200B liquid scintillation system.

Preparation of crude cell-free extracts. Mycelium harvested from yeast extract-malt extract medium supplemented with $33 \%$ (w/v) sucrose and $0.5 \%(\mathrm{w} / \mathrm{v}) \mathrm{MgCl}_{2}$ has increased sensitivity to lysozyme (Townsend, 1973). To prepare extracts such material was suspended in its own weight of extraction buffer (Io mM-tris- $\mathrm{HCl}, \mathrm{pH} 8 \cdot 3$, at $4{ }^{\circ} \mathrm{C}$; $10 \mathrm{mM}-\mathrm{MgCl}_{2}$; O. I mM-EDTA, $\mathrm{pH} 7.0 ; 0.1 \mathrm{~mm}$-dithiothreitol; I $5 \%, \mathrm{v} / \mathrm{v}$, glycerol) and incubated for $15 \mathrm{~min}$ at $30{ }^{\circ} \mathrm{C}$ with lysozyme $(2.5 \mathrm{mg} / \mathrm{ml})$. After cooling in ice, the suspension was given brief ultrasonic treatment to complete lysis of the weakened cells. Extracts were cleared by lowspeed centrifugation, then centrifuged at $78000 \mathrm{~g}$ at $4{ }^{\circ} \mathrm{C}$ for $90 \mathrm{~min}$ to remove ribosomes. Such 'crude extracts' were stored at $-20^{\circ} \mathrm{C}$ with little loss of activity over several weeks.

$R N A$ polymerase assay. The reaction mixture comprised: 60 mM-tris- $\mathrm{HCl}, \mathrm{pH} 7 \cdot 9$, at $30{ }^{\circ} \mathrm{C}$; Io $\mathrm{mM}^{-\mathrm{MgCl}_{2}}$; 0.I mM-EDTA; $50 \mathrm{mM}-\mathrm{NH}_{4} \mathrm{Cl}$; $0.15 \mathrm{~mm}-\mathrm{ATP}$, CTP, GTP and $\left[{ }^{3} \mathrm{H}\right]$ UTP (I $7 \mathrm{mCi} / \mathrm{mmol}$ ); 2 mM-spermidine; $0.375 \mathrm{~mm}$-potassium phosphate buffer, $\mathrm{pH} 7.3 ; 0.1 \mathrm{~mm}$-dithiothreitol; and calf thymus DNA at $0.05 \mathrm{mg} / \mathrm{ml}$. The total volume of the reaction mixture varied from 0.1 to $0.3 \mathrm{ml}$, as stated. After addition of crude extract, the mixture was incubated at $30{ }^{\circ} \mathrm{C}$ for $\mathrm{Io}$ min and the reaction stopped by placing in ice. Three $\mathrm{ml}$ ice-cold $5 \%$ TCA containing Io mM-sodium pyrophosphate was added. After I $5 \mathrm{~min}$ the insoluble material was collected on a glass-fibre filter presoaked in $2 \% \mathrm{TCA}+$ Io mM-sodium pyrophosphate, and washed with eight $\mathrm{I} \cdot 5 \mathrm{ml}$ volumes of $2 \% \mathrm{TCA}+\mathrm{IO} \mathrm{mM}-$ sodium pyrophosphate and finally with $3 \mathrm{ml}$ ethanol. The filter was dried at $80^{\circ} \mathrm{C}$ and its radioactivity determined as described above.

\section{RESUL T S}

The effect of rifampicin on RNA synthesis by whole cells of Streptomyces coelicolor A3(2)

RNA synthesis by whole cells was assayed by measuring the incorporation of $\left[{ }^{3} \mathrm{H}\right]$ uridine into TCA-insoluble material. Although such measurements are relatively simple with single celled organisms, where homogeneous cell suspensions can be used, the mycelial growth of Streptomyces coelicolor and its tendency to form clumps necessitated the development of a special technique. Pieces of glass-fibre filters carrying approximately similar amounts of young mycelium were prepared as described in Methods. These were incubated for various time intervals in an assay medium containing $\left[{ }^{3} \mathrm{H}\right]$ uridine, then placed in ice-cold $5 \%$ TCA, washed, and the incorporation of ${ }^{3} \mathrm{H}$ into TCA-insoluble material estimated. Although the method was rather crude, it was sufficiently reliable to be used in preliminary studies of the effect of rifampicin on RNA synthesis. Fig. 2 shows that RNA synthesis was rapidly and 


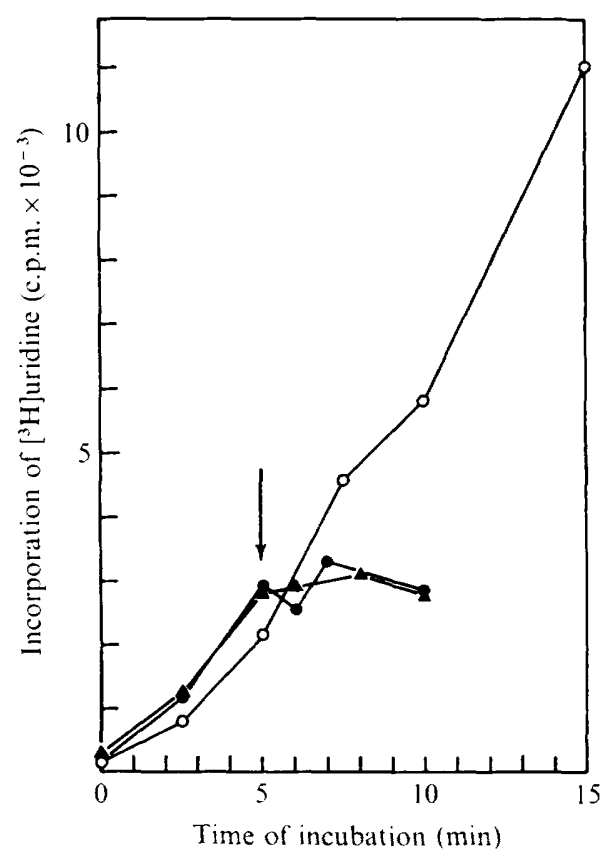

Fig. 2. RNA synthesis by whole cells of Streptomyces coelicolor in the presence of rifampicin and streptolydigin. The assays were carried out with glass-fibre quadrants carrying young mycelium as described in Methods. Each point on the graph corresponds to the mean amount of $\left[{ }^{3} \mathrm{H}\right]$ uridine incorporated into TCA-insoluble material by duplicate samples incubated for the stated time in $\left[{ }^{3} \mathrm{H}\right]$ uridine-containing assay medium. $O$, Control (no antibiotic); $\bullet$, rifampicin ( $\left.100 \mu \mathrm{g} / \mathrm{ml}\right)$ at $5 \mathrm{~min} ; \boldsymbol{\Delta}$, streptolydigin $(100 \mu \mathrm{g} / \mathrm{ml})$ at $5 \mathrm{~min}$. The arrow marks the point when antibiotic was added.

\section{Table 2. The effect of different rifampicin concentrations on RNA synthesis by whole cells of Streptomyces coelicolor}

The assays were carried out with filter quadrants as described in Methods, except that the specific activity of uridine was $0 \cdot \mathrm{r} \mu \mathrm{Ci} / \mu \mathrm{mol}$. Samples were pre-incubated in non-radioactive medium with rifampicin for $5 \mathrm{~min}$ before being transferred to assay medium containing $\left[{ }^{3} \mathrm{H}\right]$ uridine and rifampicin. The reaction was stopped at $5 \mathrm{~min}$. The means for duplicate samples in three replicate experiments are given.

\begin{tabular}{ccccc}
$\begin{array}{c}\text { Counts } / \text { min } \\
\text { in sample } \\
\begin{array}{c}\text { without } \\
\text { rifampicin }\end{array}\end{array}$ & \multicolumn{4}{c}{$\begin{array}{c}\text { Residual activity at different concentrations } \\
\text { of rifampicin }(\%)\end{array}$} \\
$2 \mu \mathrm{g} / \mathrm{ml}$ & $5 \mu \mathrm{g} / \mathrm{ml}$ & $20 \mu \mathrm{g} / \mathrm{ml}$ & $50 \mu \mathrm{g} / \mathrm{ml}$ \\
452 & 59 & 30 & 18 & 24 \\
327 & 40 & 11 & 8 & 5 \\
472 & 56 & 29 & 18 & - \\
Mean & 52 & 23 & 15 & 15
\end{tabular}

severely inhibited by the antibiotic at $100 \mu \mathrm{g} / \mathrm{ml}$, and that streptolydigin, another inhibitor of bacterial RNA polymerase (Siddhikol, Erbstoeszer \& Weisblum, I969), had a similar effect also at $100 \mu \mathrm{g} / \mathrm{ml}$. The amount of inhibition caused by different rifampicin concentrations is given in Table 2. At $2 \mu \mathrm{g} / \mathrm{ml}$ the inhibition was about $50 \%$, and even at much higher concentrations inhibition was not complete. In later experiments (Table 10) even less inhibition was observed. 
Table 3. The effect of GTP and streptolydigin on the $R N A$ polymerase activity of an extract of $S$. coelicolor $\mathrm{A3}(2)$

Details of the assay are given in Methods. The total assay volume was $0.225 \mathrm{ml}$. Results are the mean values of duplicate assays.

$\begin{array}{lc}\text { Additions and omissions } & \text { Counts/min } \\ \text { None } & 1022 \\ \text { - GTP } & 208 \\ \text { + Streptolydigin }(20 \mu \mathrm{g} / \mathrm{ml}) & 210 \\ \text { - GTP, +streptolydigin } & 183\end{array}$

Table 4. Inhibition by rifampicin of RNA polymerase activity in crude extracts of Streptomyces coelicolor A3(2)

Extract $(0.025 \mathrm{ml})$ was incubated with $0.025 \mathrm{ml}$ rifampicin or streptolydigin solution at four times the stated concentration, or with $0.025 \mathrm{ml} 5 \%(\mathrm{v} / \mathrm{v})$, methanol/water at $30{ }^{\circ} \mathrm{C}$ for $5 \mathrm{~min}$. The components of the assay were then added to give a final volume of $0.1 \mathrm{ml}$, and incubation continued for a further $10 \mathrm{~min}$, when the reaction was stopped. For further details see Methods. Percentage residual activities were calculated after subtraction of the activity obtained in the presence of streptolydigin $(20 \mu \mathrm{g} / \mathrm{ml})$ (see text).

$\frac{\text { Counts/min }}{\text {-Rifampicin }_{1213}^{+\begin{array}{c}\text { Strepto- } \\ \text { lydigin } \\ 214\end{array}}}$

$\overbrace{\begin{array}{ccc}\mathrm{I} \mu \mathrm{g} / \mathrm{ml} & 20 \mu \mathrm{g} / \mathrm{ml} & 100 \mu \mathrm{g} / \mathrm{ml} \\ 69 & 3 \mathrm{I} & 22 \\ \text { rifampicin concentrations }(\%)\end{array}}^{\begin{array}{c}\text { Residual activity at different } \\ 69\end{array}}$

The effect of rifampicin on RNA polymerase activity in crude cell-free extracts of different wild-type streptomycetes

Using the assay system described in Methods, the incorporation of tritium into TCAinsoluble material in the presence of a crude cell-free extract of Streptomyces coelicolor A3(2) was linear with time up to $15 \mathrm{~min}$ at $30^{\circ} \mathrm{C}$. At $37^{\circ} \mathrm{C}$ the reaction was faster but shorter-lived, so all the experiments reported in this paper were done at $30{ }^{\circ} \mathrm{C}$.

A somewhat variable GTP-independent component was found in some extracts, and it was necessary to know whether this was attributable to the major RNA polymerase enzyme or was independent of it. Experiments with purified RNA polymerase (K. F. Chater, unpublished) showed that the GTP-independent activity was lost during purification, indicating that it was independent of the RNA polymerase. Since a further experiment with the purified GTP-dependent enzyme also showed that streptolydigin at $20 \mu \mathrm{g} / \mathrm{ml}$ gave almost complete inhibition of activity, it was of interest to find that activity of the GTP-independent component found in crude extracts was scarcely, if at all, inhibited by streptolydigin at $20 \mu \mathrm{g} /$ $\mathrm{ml}$ (Table 3). This observation led to the use in all experiments of a duplicate control assay containing streptolydigin at $20 \mu \mathrm{g} / \mathrm{ml}$, which was equivalent to a control lacking GTP. The mean value obtained was subtracted from all readings to give a better estimate of the RNA polymerase activity.

The effect of different concentrations of rifampicin on RNA polymerase activity of Streptomyces coelicolor A3(2) is given in Table 4. The results in Tables 2 and 4 indicated that the effect of rifampicin was quantitatively and qualitatively similar in vivo and in vitro, and that the RNA polymerase of strain $\mathrm{A} 3(2)$ was far less sensitive to rifampicin than is that of other prokaryotes (Wehrli \& Staehelin, 1971). This raised the question, is strain A3(2) typical of streptomycetes in this respect? Extracts of two other streptomycetes were therefore 
Table 5. Inhibition by rifampicin of RNA polymerase activity in crude extracts of three streptomycetes

\begin{tabular}{|c|c|c|c|c|}
\hline \multirow[b]{2}{*}{ Strain } & \multicolumn{2}{|c|}{ Counts/min } & \multicolumn{2}{|c|}{$\begin{array}{c}\text { Residual activity ( } \%) \\
\text { with two rifampicin } \\
\text { concentrations }\end{array}$} \\
\hline & - Rifampicin & $\begin{array}{c}\text { + Strepto- } \\
\text { lydigin }\end{array}$ & I $\mu \mathrm{g} / \mathrm{ml}$ & $20 \mu \mathrm{g} / \mathrm{ml}$ \\
\hline A3(2) $(S$. coelicolor $)$ & 1008 & 97 & 75 & 48 \\
\hline I326 (S. lividans) & 1267 & I 88 & 83 & 46 \\
\hline I 60 (S. albus) & 1045 & 220 & I & 0 \\
\hline
\end{tabular}

The procedure and calculations were as in Table 4 except that all quantities in the assay mixture were doubled, giving a final volume of $0.2 \mathrm{ml}$, and the extracts were pre-incubtaed for only 2 min with rifampicin.

Table 6. Preliminary mapping of the rif-IOI mutation

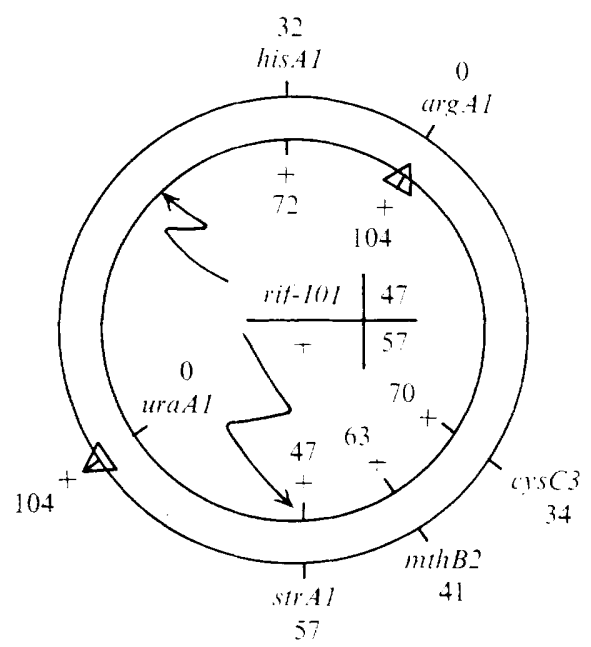

\begin{tabular}{l|cc} 
& hisAI & + \\
\hline rif-IOI & 12 & 35 \\
+ & 20 & 37
\end{tabular}

\begin{tabular}{l|cc} 
& strAI & + \\
\hline rif-IOI & 0 & 47 \\
+ & 57 & 0
\end{tabular}

Strain 782 (outer circle) was crossed with the rifampicin-resistant strain $\mathbf{J 2 2 2}$ (inner circle) and selection was made for recombinants inheriting arg $^{+}$and ura $^{+}$(triangles). The frequency of each allele among the progeny is given on the diagram, together with alternative locations (arrows) for rif-IOI based on its allele frequency. Examination of the pattern of recombination shows absence of recombination between strAI and rif-IOI (giving strAIrif-IOI or str $A^{+}$rif $^{+}$ recombinants) and independent assortment of his $A I$ and rif-IOI indicating a location of rif-IOI close to $\operatorname{str} A$.

made and the effects of rifampicin on their RNA polymerase activity were measured (Table 5). It turned out that strain 1326 was very similar to A3(2), whereas strain I I6o, which in other respects also is less similar to $\mathrm{A} 3(2)$ than is 1326 , differed considerably: its activity was completely inhibited by rifampicin at $\mathrm{I} \mu \mathrm{g} / \mathrm{ml}$, at which concentration the $\mathrm{A} 3(2)$ and $\mathrm{I} 326$ activities were only slightly affected $(25 \%$ and $17 \%$, respectively). It is unlikely that the results with the I 60 extract can be partially attributed to a lower sensitivity of its enzyme to streptolydigin than was found for A3(2) (thus causing a falsely high estimate of RNA polymerase-independent ${ }^{3} \mathrm{H}$ incorporation), or to sensitivity to rifampicin of the streptolydigin- 
resistant component: the inhibition obtained with rifampicin or streptolydigin at either I $\mu \mathrm{g} / \mathrm{ml}$ or $20 \mu \mathrm{g} / \mathrm{ml}$ was approximately the same, and no reduction of the streptolydiginresistant activity was observed in the presence of rifampicin (K. F. Chater, unpublished).

\section{Rifampicin-resistant mutants}

In the first isolation, a large number of rifampicin-resistant (rif) mutants were isolated from strain A32I as papillae on the surface of a confluent layer of growth after 4 days' incubation on plates containing $100 \mu \mathrm{g}$ of rifampicin $/ \mathrm{ml}$. Four of these were crossed with strain 782, and all gave similar results. In the example shown in Table 6 the allele frequencies located rif-IOI either between hisAI and $u r a A I$, or very close to $\operatorname{str} A I$. Since rif-ror segregated independently of hisAI $\left(\chi_{1}^{2}=\mathrm{I} \cdot \mathrm{I}\right)$ but not of $\operatorname{str} A I\left(\chi_{1}^{2}=104\right)$, it was concluded that rif-Ior was located very close to strAI, identifying the rif $A$ locus.

The very close linkage of rif-Ior and strAI made it easy to carry out a rapid method of identifying rif mutations located elsewhere on the linkage map. Up to 24 mutants per plate were inoculated as patches over a template and allowed to grow and sporulate, before replica plating to CM spread with spores of strain 782 (see Table 6 for diagram of marker arrangements), thus giving 24 crosses on a single plate. After 4 days' incubation, the plates were replica plated to appropriately supplemented MM selecting $\operatorname{str} A I$ from strain 782 and the diametrically situated $h i s A^{+}$from the rifampicin-resistant strains. Clearly, recombinants arising from crosses with strains in which the rif mutation was closely linked to strA would nearly all have received the rif $^{+}$allele of strain 782 , and would therefore be rifampicinsensitive. On the other hand, where the rifampicin-resistant parent strain had a rif mutation not very closely linked to $\operatorname{str} A I$, a significant proportion of streptomycin-resistant recombinants would also be rifampicin-resistant. The selective plates containing streptomycin were therefore incubated for 4 days and replica plated to similar plates containing rifampicin. Fifty-nine rifampicin-resistant mutants from the first mutant isolation were tested by this method. Nearly all possessed rif mutations closely linked to str $A$; however, two gave a high frequency of strA rif recombinants, indicating fairly close linkage between hisAI and the rif mutation. Similar rapid mapping was done with 54 mutants from four subsequent isolations, in which different starting strains and post-mutagenic treatments were employed. Seventeen more examples were found of mutations located near to his $A$, together with a single example of a third type of mutant giving intermediate frequencies of str $A$ rif recombinants on the plate test. his $A$-linked mutations were only found among mutants which had been isolated on lower concentrations (50 to $100 \mu \mathrm{g} / \mathrm{ml}$ ) of rifampicin, and the third type of mutant was also isolated on $50 \mu \mathrm{g} / \mathrm{ml}$. Thus, all rif mutants isolated on a high concentration $(200 \mu \mathrm{g} / \mathrm{ml})$ of rifampicin possessed str $A$-linked mutations. The mutant spectrum was not related to the mutagen employed or to the kind of post-mutagenic treatment.

\section{More precise genetic mapping of hisA-linked rif mutations}

The independently isolated his $A$-linked rif mutations were shown in preliminary crosses with strain 782 to be located close to, and anticlockwise of, his $A$; in the example given in Table 7, a choice between the two alternative locations suggested by consideration of the allele frequency is easily made, because the segregation of rif-I03 was independent of ${ }_{\text {cys }} C_{3}\left(\chi_{1}^{2}=0.5\right)$, but not of hisAI $\left(\chi_{1}^{2}=58\right)$.

Further crosses of these and two other mutants with strain 876 (data not given) indicated a map location between proAI and hisAI; a similar result was also obtained with crosses of strain A32I with two resistant derivatives of strain 876 . Since all the data were similar, it 
Table 7. Preliminary genetic mapping of the rif-103 mutation

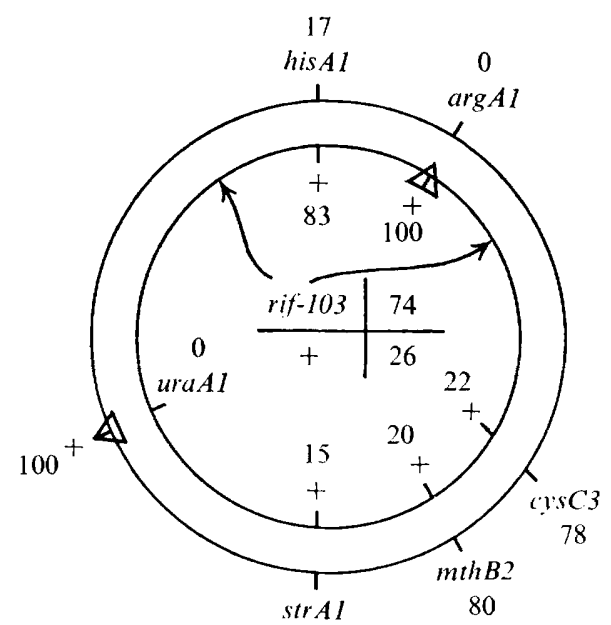

85

\begin{tabular}{c|cc} 
& hisAr & + \\
\hline rif-103 & 0 & 74 \\
+ & 17 & 9
\end{tabular}

\begin{tabular}{l|cr} 
& cys $C_{3}$ & + \\
\hline rif-103 & 59 & 15 \\
+ & 19 & 7
\end{tabular}

Strain 782 (outer circle) was crossed with the rifampicin-resistant strain J229 (inner circle) and selection was made for recombinants inheriting $\mathrm{uraA}^{+}$and $\operatorname{arg~A^{+}}$ (triangles). The frequency of each allele among the progeny is given on the diagram, together with alternative locations (arrows) for rif-103 based on its allele frequency. The tabulations show clearly that rif-103 segregated independently of $c_{3 s} C_{3}$ but not of his $A I$, indicating the location between his $A$ and $u r a A$.

seemed probable that only one locus was involved, so two representative mutations were selected for use in further mapping studies to determine its location. Recombinants had been obtained from the crosses with 876 having the rif mutations in combination with proAI. These were crossed with strains 3 I I and 957, to locate the rif mutations with respect to the $l e u A$ and thiC genes (Table 8). It was clear that both mutations were situated anticlockwise of $t h i C$, and that rif-IO3 was clockwise of leuA. The data for the location of rif-Io9 with respect to $l e u A$ were less clear, and there were relatively few leuA rif recombinants. A cross between hisC 9 rif-Io3 and proAI rif-Iog recombinants gave 96 resistant colonies out of 98 scored, a result showing that rif- 109 was situated either clockwise of rif-IO3 (when the two sensitive recombinants would have resulted from multiple crossing over) or anticlockwise of rif-103 but very close to it. Consideration of this result leads to the conclusion that the rif-rog mutation, like rif-ro3, is situated between leuA and thiC. In the absence of more detailed information, all the his $A$-linked rif mutations obtained so far are considered to be mutations in one gene, termed rifB.

\section{Genetic mapping of the rif-II4 mutation}

The rif mutation in strain $\mathrm{J} 259$ (uraAIrif-r I4) was recognized as being distinct from rifA and rif $B$ mutations by rapid mapping tests. In a preliminary cross with strain 876 (Table 9) the allele frequency gave the location of the mutation as either between phe $A$ and $\operatorname{str} A$, or between $u r a A$ and pro $A$; analysis of the segregation pattern showed that the former location was correct, as the segregation of rif-II4 was almost independent of that of proAI $\left(\chi_{1}^{2}=\right.$ 
Table 8. More precise location of rifB mutations

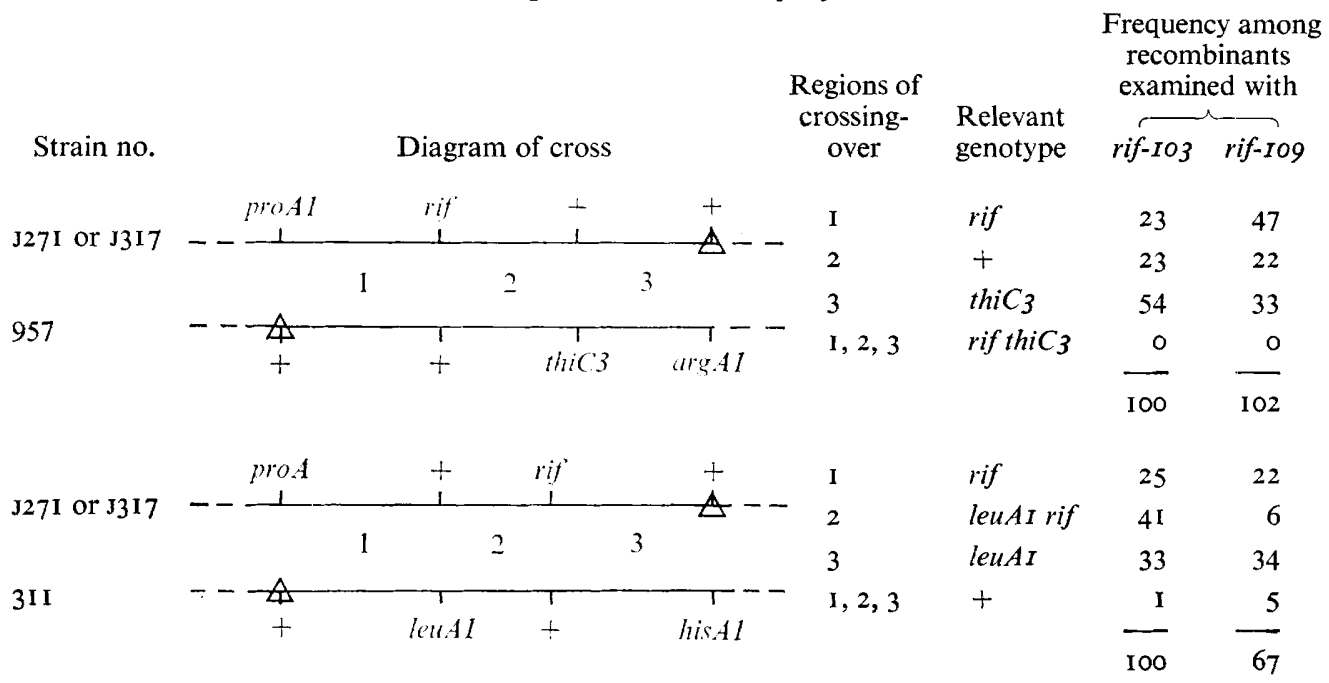

Strains J27I and J3 7 were crossed with strains 957 and $3 \mathrm{I}$ I, with the selections indicated by triangles in the diagrams. For further explanation, see text.

$5 \cdot 6)$ but not of phe $A I\left(\chi_{1}^{2}=63\right)$. The data of Table 9 clearly show that rif-II4 is not close to $\operatorname{sir} A$, to which rif $A$ mutations are very closely linked. To confirm that rif-II4 was indeed distinct from mutations at the rif $A$ locus a cross of strain J30I (pheArrif-I 14) with $\mathbf{J} 223$ (cys $C$ 3rif $A 10 I$ ) was made, with selection for prototrophic recombinants. Sixty recombinants out of 102 tested were sensitive to rifampicin, confirming that rif-II4 was not a rif $A$ allele and was located clockwise of rif $A$. It was taken to be the unique representative of a third rifampicin-resistance locus, rifC.

The effect of rifampicin on RNA synthesis by whole cells and extracts of rifampicin-resistant mutants

Representative mutants possessing rifAIOI, rifBI25 and rifCII4 were initially examined. The results for the rif $B$ and $C$ mutants with whole cells differed strikingly from those with extracts: incorporation of $\left[{ }^{3} \mathrm{H}\right]$ uridine into whole cells was scarcely affected by rifampicin (up to $20 \mu \mathrm{g} / \mathrm{ml}$ ) whereas in extracts the pattern of rifampicin-sensitivity of RNA polymerase was much the same as in the wild type (Table 10). From these results it seemed probable that the rif $B$ and $C$ mutants owed their rifampicin resistance to a reduced ability of the cell to take up the antibiotic. In contrast, the results for the rifAIor mutant were closely similar in whole cells and extracts, in both cases indicating little difference from the wild type. To clarify this result, several other rifA mutants which had been isolated on relatively high rifampicin concentrations (up to $200 \mu \mathrm{g} / \mathrm{ml}$ ) were tested (Table 10 ), and their RNA polymerase activities were found to have greatly increased resistance to rifampicin compared with the wild type. There was even some evidence for stimulation of activity by rifampicin with some extracts: no experiments have been made to determine the nature of this stimulation. Overall, the results in Table Io constitute strong preliminary evidence that rif $A$ mutants possess RNA polymerase altered in its rifampicin sensitivity. 
Table 9. Preliminary genetic mapping of the rif-r 44 mutation

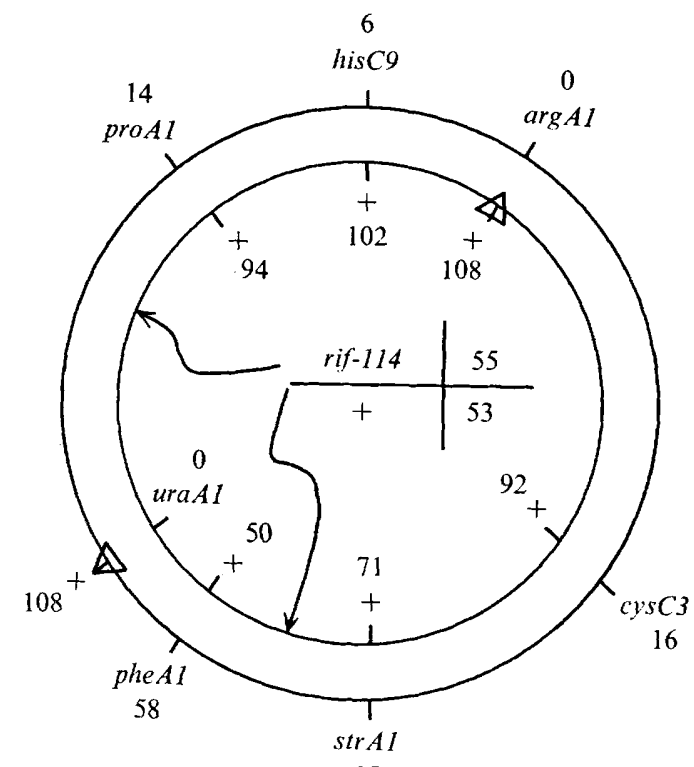

37

\begin{tabular}{l|rr} 
& proAr & + \\
\hline \begin{tabular}{r|r} 
rif-II4 \\
+
\end{tabular} & 3 & 52 \\
11 & 42
\end{tabular}

\begin{tabular}{l|cr} 
& phe $A I$ & + \\
\hline rif-II4 & 9 & 46 \\
+ & 49 & 4
\end{tabular}

Strain 876 (outer circle) was crossed with strain $\mathbf{J} 259$ (inner circle) and selection was made for recombinants inheriting $\mathrm{ura}^{+}$and $\mathrm{arg}^{+}$(triangles). The frequency of each allele among the progeny is given on the diagram, together with alternative locations (arrows) for rif-I I 4 based on its allele frequency. The tabulations show that segregation of rif-II 4 is much more dependent on that of phe AI than of proAI, indicating the location between phe $A$ and str $A$.

\section{The morphology of rif mutants}

In the course of this work about a hundred mutants presumed on the basis of genetic mapping to be rif $A$ have been isolated. In one isolation experiment many mutants were devoid of aerial mycelium ('bald'), and three other 'bald' rif $A$ mutants were obtained in separate isolations. However, despite this apparently high rate of coincidence of the rif $A$ mutation and morphological abnormality, in each case the bald mutation segregated from the rif $A$ mutation in crosses. Thus we have no evidence of a morphological effect resulting from an altered RNA polymerase, in constrast to the situation described for Bacillus subtilis (Sonenshein \& Losick, 1970; Doi et al. 1970).

\section{DISCUSSION}

The results in this paper have shown that streptomycetes, like other prokaryotes, possess rifampicin-sensitive RNA polymerase, though the degree of sensitivity is relatively low in some wild-type strains: it was found that while the Streptomyces albus (strain 1160) enzyme was almost completely inhibited by rifampicin concentrations as low as $0.0 \mathrm{I} \mu \mathrm{g} / \mathrm{ml}$ (Table 5 ; and K.F. Chater, unpublished), a concentration of the order of $10 \mu \mathrm{g} / \mathrm{ml}$ was required to give $50 \%$ inhibition of the enzyme of two more closely related strains, $S$. coelicolor A3(2) and 
Table I0. The effect of rifampicin on RNA synthesis by whole cells and extracts of rifampicin-resistant mutants of Streptomyces coelicolor A3(2)

\begin{tabular}{|c|c|c|c|c|c|c|c|}
\hline \multirow[b]{2}{*}{ Strain } & \multirow{2}{*}{$\begin{array}{l}\text { rif } \\
\text { mutation }\end{array}$} & \multirow{2}{*}{$\begin{array}{l}\text { Whole cells } \\
\text { or extract }\end{array}$} & \multirow{2}{*}{$\begin{array}{c}\text { Total } \\
\text { activity } \\
\text { with no } \\
\text { inhibitor } \\
\text { (counts/ } \\
\text { min) }\end{array}$} & \multirow{2}{*}{$\begin{array}{l}\text { Activity } \\
\text { with } \\
\text { strepto- } \\
\text { lydigin } \\
\text { (counts/ } \\
\text { min) }\end{array}$} & \multicolumn{3}{|c|}{$\begin{array}{l}\text { Residual activity }(\%) \text { at various } \\
\text { concentrations of rifampicin }\end{array}$} \\
\hline & & & & & $5 \mu \mathrm{g} / \mathrm{ml}$ & $20 \mu \mathrm{g} / \mathrm{ml}$ & $100 \mu \mathrm{g} / \mathrm{ml}$ \\
\hline $\mathrm{A} 3(2)$ & - & Whole cells & 5109 & 一 & 65 & 39 & 一 \\
\hline $\mathrm{A} 3(2)$ & - & Extract & $45^{8}$ & I I 5 & 58 & 38 & 22 \\
\hline $\left.\begin{array}{l}\mathrm{J} 223 \\
\mathrm{~J} 222\end{array}\right\}$ & rif $A I O I$ & $\left\{\begin{array}{l}\text { Whole cells } \\
\text { Extract }\end{array}\right.$ & $\begin{array}{r}4885 \\
671\end{array}$ & $\overline{166}$ & $\begin{array}{l}56 \\
43\end{array}$ & $\begin{array}{l}39 \\
32\end{array}$ & 13 \\
\hline $\left.\begin{array}{l}\mathbf{J} 386 \\
\mathbf{J} 373\end{array}\right\}$ & rifBI25 & $\left\{\begin{array}{l}\text { Whole cells } \\
\text { Extract }\end{array}\right.$ & $\begin{array}{l}2735 \\
1176\end{array}$ & $\overline{498}$ & $\begin{array}{l}96 \\
39\end{array}$ & $\begin{array}{l}72 \\
23\end{array}$ & - \\
\hline $\left.\begin{array}{l}\text { J30I } \\
\text { J259 }\end{array}\right\}$ & rifCII4 & $\left\{\begin{array}{l}\text { Whole cells } \\
\text { Extract }\end{array}\right.$ & $\begin{array}{r}3731 \\
713\end{array}$ & - & $\begin{array}{l}89 \\
30\end{array}$ & $\begin{array}{l}58 \\
16\end{array}$ & - \\
\hline $\mathrm{J} 372$ & rif $A I 24$ & $\begin{array}{l}\text { Whole cells } \\
\text { Extract }\end{array}$ & $\begin{array}{r}4075 \\
541\end{array}$ & 113 & 69 & $\begin{array}{r}77 \\
150\end{array}$ & - \\
\hline J51 5 & rif $A$ I 26 & $\begin{array}{l}\text { Whole cells } \\
\text { Extract }\end{array}$ & $\begin{array}{r}3147 \\
380\end{array}$ & - & $\underline{108}$ & $\begin{array}{l}97 \\
9 \mathrm{I}\end{array}$ & $\overline{71}$ \\
\hline $\mathrm{J} 264$ & rif $A I I 8$ & Extract & 264 & 117 & - & 77 & 90 \\
\hline J398 & rif $A 122$ & Extract & 452 & 105 & - & I I 3 & 107 \\
\hline
\end{tabular}

* For strain $\mathrm{J} 259$ the streptolydigin control was replaced by a control lacking GTP, which gave 5I counts/ $\min$.

S. lividans (strain 1326). Since the RNA polymerase activity of A3(2) has a similar profile of rifampicin sensitivity in whole cells, in crude extracts, and in highly purified preparations (TableIo; and K.F. Chater, unpublished), the relatively low rifampicin-sensitivity cannot easily be accounted for either by pre-attachment of the enzyme to endogenous DNA to form a rifampicin-resistant complex (Sippel \& Hartmann, 1970), or by rifampicin breakdown or removal by factors present in extracts.

The isolation of mutants which appear to have decreased permeability to rifampicin has been described for Escherichia coli (Patterson, Weinstein, Marshall \& Gillespie, I97I) and Bacillus subtilis (Brown \& Doi, I970). In the case of E. coli, the Rif-r (permeability) mutations are closely linked, but complementary, to rif $A$ mutants having an altered RNA polymerase (Marshall \& Gillespie, I972). In Streptomyces coelicolor there are two loci, rifB and rifC, in which mutations seem to result in reduced permeability of cells to rifampicin. These are not closely linked to each other, or to the rif $A$ locus. The evidence that rif $A$ specifies the rifampicin-sensitive component of RNA polymerase is supported by recent experiments (K. F. Chater, unpublished) in which RNA polymerase of a rifA mutant has been purified about 40-fold through to the DEAE cellulose step of Burgess (1969): such enzyme retained its resistance to rifampicin.

Close linkage of the gene for rifampicin-resistant RNA polymerase with loci specifying antibiotic-resistant ribosomes has been noted in Bacillus subtilis (Harford \& Sueoka, 1970). Moreover, conservation of this gene arrangement and of the nucleotide sequences involved are indicated by the finding that the rate of transformation between various 
Bacillus species is much higher for rifampicin- and erythromycin-resistance genes than for auxotrophic markers, and that co-transformation is usually detectable (Harford \& Mergeay, 1973). It is thus interesting to find that str $A$ and rif $A$ are also very closely linked in Streptomyces coelicolor; one would like to know, in the context of our understanding of the meaning of the arrangement of genes on the bacterial chromosome, whether they are also rather closely linked to the origin of replication in $S$. coelicolor as has been found in B. subtilis (Harford \& Sueoka, 1970), Escherichia coli (Taylor, I970; Bird, Louarn, Martuscelli \& Caro, 1972) and Salmonella typhimurium (Sanderson, 1970; Nishioka \& Eisenstark, 1970).

Morphological abnormalities attributable to rifA mutations were not found in Streptomyces coelicolor, though they are frequently encountered in Bacillus subtilis (Sonenshein \& Losick, 1970; Doi et al. 1970). This does not of course exclude the possibility that changes of RNA polymerase structure and/or specificity are involved in differentiation in $S$. coelicolor, though it suggests that if any such changes do occur they probably involve regions of the enzyme distinct from the rifampicin binding site.

The indispensable technical assistance of Judith M. Humphries is gratefully acknowledged. I should also like to thank all those patient colleagues who have given me biochemical advice; Professor D. A. Hopwood for help in various ways and for reading the manuscript; F. Wright for performing the experiments in Table 5; and Mrs M. Limberg for preparing the typescript.

\section{REFERENCES}

Bird, R. E., Louarn, J., Martuscelli, J. \& Caro, L. (1972). Origin and sequence of chromosome replication in Escherichia coli. Journal of Molecular Biology 7o, 549-566.

Brown, L. R. \& DoI, R. H. (I970). Rifampicin and streptovaricin resistant mutants of B. subtilis. Bacteriological Proceedings, I3I.

Burgess, R. R. (1969). A new method for the large scale purification of Escherichia coli deoxyribonucleic acid-dependent ribonucleic acid polymerase. Journal of Biological Chemistry 244, 6160-6167.

ChATER, K. F. (1972). A morphological and genetic mapping study of white colony mutants of Streptomyces coelicolor. Journal of General Microbiology 72, 9-28.

Chater, K. F. \& Hopwood, D. A. (1973). Differentiation in Actinomycetes. Symposium of the Society for General Microbiology 23, r43-160.

Delić, V., Hopwood, D. A. \& Friend, E. J. (1970). Mutagenesis by $N$-methyl- $N^{\prime}$-nitro- $N$-nitrosoguanidine (NTG) in Streptomyces coelicolor. Mutation Research 9, I67-182.

Dor, R. H., Brown, L. R., Rodgers, D. \& Hsu, Y. (1970). B. subtilis mutant altered in spore morphology and in RNA polymerase activity. Proceedings of the National Academy of Sciences of the United States of America 66, 404-410.

HARFord, N. \& MERGEAY, M. (1973). Interspecific transformation of rifampicin resistance in the genus Bacillus. Molecular and General Genetics 120, I 5 I-I 55.

HARFord, N. \& SueOKA, N. (1970). Chromosomal location of antibiotic resistance markers in Bacillus subtilis. Journal of Molecular Biology 5I, 267-286.

HAROLD, R. J. \& HopwoOd, D. A. (1972). A rapid method for complementation testing of ultravioletsensitive (uvs) mutants of Streptomyces coelicolor. Mutation Research 16, 27-34.

Hopwood, D. A. (1959). Linkage and the mechanism of recombination in Streptomyces coelicolor. Annals of the New York Academy of Sciences 81, 887-898.

Hopwood, D. A. (1967). Genetic analysis and genome structure in Streptomyces coelicolor. Bacteriological Reviews 31, 373-403.

Hopwood, D. A., Chater, K. F., Dowding, J. E. \& Vivian, A. (I973). Advances in Streptomyces coelicolor genetics. Bacteriological Reviews (in the Press).

Hopwood, D. A., Harold, R. J., Vivian, A. \& Ferguson, H. M. (1969). A new kind of fertility variant in Streptomyces coelicolor. Genetics, Princeton 62, 46I-477.

Hopwood, D. A., Wildermuth, H. \& PAlmer, H. M. (1970). Mutants of Streptomyces coelicolor defective in sporulation. Journal of General Microbiology 6r, 397-408. 
Hopwood, D. A. \& WRIGHT, H. M. (I973). Transfer of a plasmid between Streptomyces species. Journal of General Microbiology 77, 187-195.

KutzNer, H. J. \& Waksman, S. A. (1959). Streptomyces coelicolor Müller and Streptomyces violaceoruber Waksman and Curtis, two distinctly different organisms. Journal of Bacteriology 78, 528-538.

Lomovskaya, N. D., Mkrtumian, N. M., Gostimskaya, N. L. \& Danilenko, V. N. (I972). Characterisation of temperate actinophage $\phi \mathrm{C}_{3}$ I isolated from Streptomyces coelicolor A3(2). Journal of Virology $\mathbf{9}$, $258-262$.

Marshall, S. \& Gillespie, D. (1972). New rifampicin-resistant mutant of Escherichia coli. Journal of Bacteriology 110, 782-783.

Nishiok A, Y. \& EISENSTARK, A. (1970). Sequence of genes replicated in Salmonella typhimurium as examined by transduction techniques. Journal of Bacteriology 102, 320-333.

Patterson, D., Weinstein, M., Marshall, S. \& Gillespie, D. (1971). A new RNA synthesis mutant of E. coli. Biochemical Genetics 5, 563-578.

Sanderson, K. E. (1970). Current linkage map of Salmonella typhimurium. Bacteriological Reviews 34, $176-193$.

Siddhikol, C., Erbstoeszer, J. \& Weisblum, R. (i969). Mode of action of streptolydigin. Journal of Bacteriology 99, 15 I-I 55.

Sippel, A. \& HARTMANn, G. (1970). Rifampicin resistance of RNA polymerase in the binary complex with DNA. European Journal of Biochemistry 16, I 52-1 57.

SONENSHEIN, A. L. \& Losick, R. (1970). RNA polymerase mutants blocked in sporulation. Nature, London 227, 906-909.

TAYLor, A. L. (1970). Current linkage map of Escherichia coli. Bacteriological Reviews 34, I $55-175$.

ToWnsend, M. E. (1973). Genetic studies on Streptomyces scabies. M.Phil. Thesis, University of East Anglia. Townsend, M. E., Wright, H. M. \& Hopwood, D. A. (1971). Efficient mutagenesis by near ultraviolet light in the presence of 8-methoxypsoralen in Streptomyces. Journal of Applied Bacteriology 34, 799-801.

Wehrli, W. \& Staehelin, M. (I97I). Actions of the rifamycins. Bacteriological Reviews 35, $290-309$. 